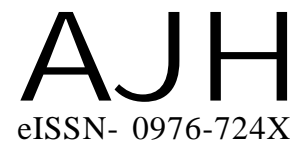

Received : 18.02.2017

Revised : 26.04.2017

Accepted : 10.05.2017

Members of the Research Forum

Associated Authors:

${ }^{1}$ Department of Agriculture,

Bhagwant University, AJMER

RAJASTHAN) INDIA

${ }^{2}$ Department of Agricultural Biotechnology Bhagwant University, AJMER (RAJASTHAN) INDIA
Author for correspondence : RAJENDRA MANDA

Department of Agriculture,

Bhagwant University, AJMER

(RAJASTHAN) INDIA

Email : chenaram9571@gmai.com
THE ASIAN JOURNAL OF HORTICULTURE

Volume $12 \mid$ Issue $1 \mid$ June, 2017 | 63-74

Visit us -www.researchjournal.co.in

\title{
Triticum aestivum L. varietal accession evaluation under low fertility and two irrigations
}

RAJENDRA MANDA, DEVENDRA SINGH ${ }^{1}$ AND BHANWAR LAL JAT ${ }^{2}$ ABSTRACT : The experiment consisted of 9 treatments viz., $\mathrm{T}_{0}$ (DBW -17), $\mathrm{T}_{1}$ (Raj 3077), $\mathrm{T}_{2}$ (HD 2967), $\mathrm{T}_{3}$ (Lok-1), $\mathrm{T}_{4}$ (Raj 1482), $\mathrm{T}_{5}\left(\right.$ Raj 4120), $\mathrm{T}_{6}(\mathrm{~K}-65) \mathrm{T}_{7}(\mathrm{HD} 2967), \mathrm{T}_{8}(\mathrm{PBW}-343)$ laid out in Randomized Block Design with three replications. The study showed that Lok-1variety gave highest grain yield (2.76t ha $\left.{ }^{-1}\right)$, harvest index (31.15\%), highest net income (Rs. 110,000.7 ha-1) and benefit: cost (3.74) then the rest of the varieties. The plant height was found to be the highest under the treatment $T_{3}$ (Lok-1) at 30,60 and 90DAS the differences were statistically significant. Treatment $T_{1}$ (Raj 3077) recorded significantly higher number of effective tillers per meter square than all the other treatments, while the lowest number of effective tillers per meter square was recorded for the treatment $\mathrm{T}_{3}$ (Lok-1). The spike length was recorded to be highest under the treatment $\mathrm{T}_{3}$ (Lok-1) which was significantly higher than all these other treatments, while the lowest spike length was recorded under the treatment $T_{5}$ (Raj 4120). Number of grains spike $^{-1}$ was recorded to be highest under the treatment $\mathrm{T}_{6}(\mathrm{~K}-65)$, while the lowest grains spike${ }^{1}$ was recorded under the treatment $\mathrm{T}_{0}(\mathrm{DBW}-17)$. Treatment $\mathrm{T}_{2}$ (HD2967) recorded significantly higher test weight than all the other treatments, while the lowest test weight was recorded under the treatment $\mathrm{T}_{8}$ (PBW-343). The highest grain yield was recorded under the treatment $\mathrm{T}_{3}$ (Lok1 ), while the lowest grain yield was recorded in treatment $T_{0}(\mathrm{DBW}-343)$ and the differences were statistically non-significant.

KEY WORDS : CGR, MOP, RGR, SSR, Harvest index, NS

HOW TO CITE THIS ARTICLE : Manda, Rajendra, Singh, Devendra and Jat, Bhanwar Lal (2017). Triticum aestivum L. varietal accession evaluation under low fertility and two irrigations. Asian J. Hort., 12(1) : 63-74, DOI : 10.15740/HAS/TAJH/12.1/63-74. 